\title{
The effect of tamoxifen and luteinizing hormone-releasing hormone (LHRH) analogue on estrogen level in women with breast cancer
}

https://doi.org/10.32792/utq/utj/vol10/2/4

\author{
Enas Abdul Kareem Jabbar \\ Prof. Saad Hammad \\ Thi- Qar university / science college Karbala university / Education college for \\ pure sciences \\ E-mail: enas kareemenaskareem@ yahoo.com \\ E-mail: dr.saad hamad @ \\ yahoo.com \\ ASS. Prof. Salwa Jaber \\ Ass. Lecturer Dhuha salem \\ AL- Nahrain university / Forensic DNA \\ AL- Nahrain university / Forensic \\ DNA for research \\ for research and training center \\ and training center
}

E-mail : dhuha.salim@ yahoo.com E-mail : salwa f.j @ yahoo.com

\begin{abstract}
Estrogen exposure is a major risk factor for breast cancer. Increased estrogen responsiveness of breast epithelium may enhance this effect.

Surgical or medical castration and antiestrogenic treatment with tamoxifen are common endocrine treatments for premenopausal women with breast cancer.

However, tamoxifen therapy induces high levels of plasma estradiol, with unknown long-term effects. In this study, we investigated the effect of combining the luteinizing hormone-releasing hormone agonist with tamoxifen and measuring estradiol level . method : Are taking random samples of breast cancer patients under treatment of patients attending the Institute of Atomic Radiation in Baghdad, and specifically who use Tamoxifen ( $20 \mathrm{mg} /$ day) . 100 samples and 30 sample as a control there age $(20-80)$. Approximately $3 \mathrm{ml}$ of blood are collected from each women using standard procedures. And then measuring the level of estradiol E2 hormone ,Measurement of the liver enzymes ( GOT,GPT,ALP,LDH and GGT ) and billirubin for study the liver health results : combined treatment with tamoxifen and
\end{abstract}




\section{University of Thi-Qar Journal Vol.10 No.2 June 2015}

Web Site: https://jutq.utq.edu.iq/index.php/main Email: journal@jutq.utq.edu.iq

LHRH analogue cause reduced in estradiol level $(37.3634 \pm 45.02893) \mathrm{P} \leq 0.01$ which is consider the main cause of breast cancer in this study group while the control group was in normal range $(93.3700 \pm 51.07188)$ and the level of liver enzymes and total billirubin was in normal range and there was no significant change. Conclusion : combining the luteinizing hormone-releasing hormone agonist with tamoxifen leads to reduced the level of estradiol E2 hormone while treatment tamoxifen alone cause elevating these hormone, also these drugs didn't effected on the liver health.

\section{على مستوى LHRHتأثير اقتران العلاج بالتاموكسيفين ونظائر هرمون} الاستروجين في النساء المصابات بسرطان الثدي

أ. سعد حمد عبد اللطيف

جامعة كربلاء / كلية التربية للعلوم الصرفة الطيفة

م.م. ضحى سالم نعمة

جامعة النهرين / مركز DNA جامعة النهرين / مركز

للبصمة الوراثية

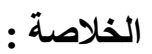

إن التعرض لهرمون الاستروجين يعتبر من أهم واخطر عوامل الإصابة بسرطان الثدي وكذلك إن زيادة مستوى هرمون الاستروجين قد يحث زيادة الاستجابة والنمو في نسيج الثذي , العلاج بواسطة تثبيط

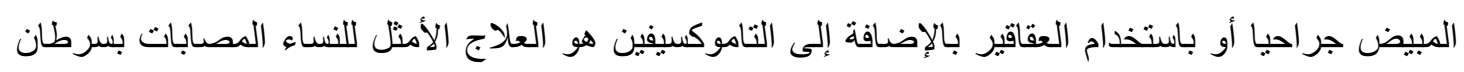
الثي قبل سن اليأس.

$$
\text { أما عند استخدام التاموكسيفين لوحده فيعمل على حث ارتفاع مستوى هرمون الاستروجين في }
$$

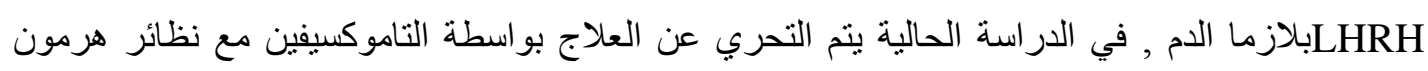

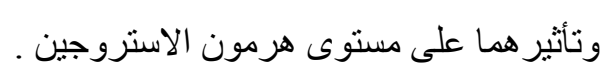

$$
\begin{aligned}
& \text { طريقة العمل : اخذت عينات عشوائية من مريضات سرطان الثذي اللاتي يخضعن للعلاج (اندات }
\end{aligned}
$$

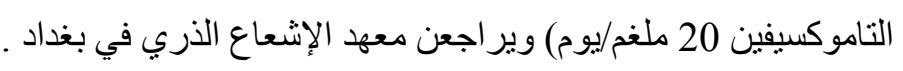

$$
\begin{aligned}
& 100 \text { عينة من النساء المريضات و } 30 \text { عينة عشوائية من النساء الطبيعيات واللاتي يتراوح } \\
& \text { أعمارهن ( 20-80) , اخذ 3مل تقريبا من الدم لكل أمر اه باستخدام طريقة قياسية وبعدها تم قياس كل من من لن } \\
& \text { و البيليروبين الكلي ( GOT,GPT,ALP,LDH and GGT ) , قياس إنزيمات الكبد E2 الاستر ادايول } \\
& \text { لملاحظة صحة الكبد. }
\end{aligned}
$$


Web Site: https://jutq.utq.edu.iq/index.php/main Email: journal@jutq.utq.edu.iq

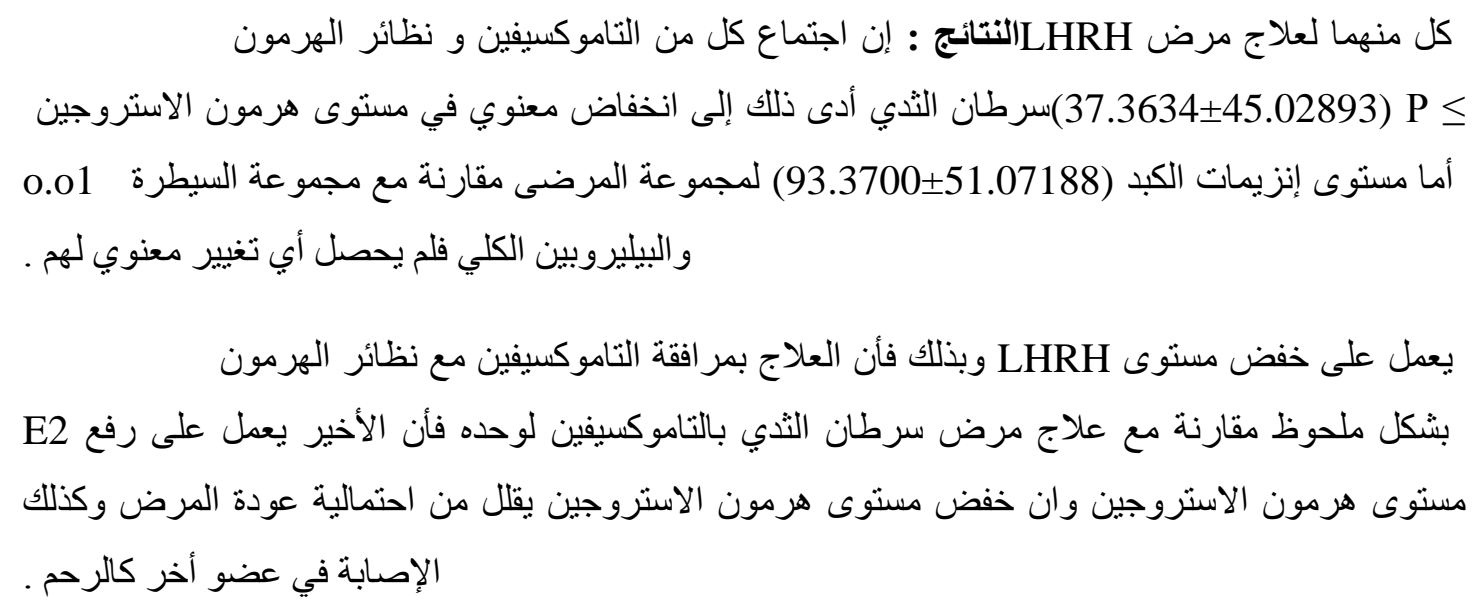

\section{INTRODUCTION}

Breast cancer is a major public health problem. It is the most common malignancy in women. Breast cancer accounts for one-third of all cancers in females and $24 \%$ of the patients are younger than 55 years of age. The number of women with breast cancer is increasing. Each year, over 1.1 million females worldwide are diagnosed with breast cancer and 410,000 women die of the disease.( Hulka ., 1996)

According to Iraqi Cancer registry 2008 there is an increase in the frequency of breast cancer incidence from 31\% in 2005(Iraqi Cancer Registry,2005) to $34 \%$ in 2008. Breast cancer occupy the first degree in the commonest ten cancer in Iraq with number of cases about 2729(19.25\%)

Endogenous hormones like estrogen are believed to play a central role in breast cancer development (Bernstein \& Ross ., 1993 ; mark et al ., 2007 ).

The predominant form of circulating estrogen in women is estradiol (Stanczyk.,1997) Estradiol(17-beta-estradiol or $\mathrm{E}_{2}$ ) a steroid hormone is derived from cholesterol,targets a variety of tissues ,is located in female and male reproductive tracts ,mammary glands skeletal and cardiovascular systems (Hall et al.,2001).Among women,it is primarily synthesized in ovarian follicles whereas in among men is produced by the testes and from extraglandular conversion of androgen (Tivis et $a l ., 2005)$.In women estradiol synthesis normally declines after menopause (Manly \& Merchant.,2000).

Estrogen is an important steroid hormone involved in regulating the differentiation and proliferation of normal breast epithelial cells(Goldfien \& Monroe.,1997 ; Allred et al ., 2004 ).Breast development at puberty and during sexual maturity is stimulated by estradiol hormone(Russo \& Russo.,2005). 


\section{University of Thi-Qar Journal Vol.10 No.2 June 2015}

Web Site: https://jutq.utq.edu.iq/index.php/main Email: journal@jutq.utq.edu.iq

Circulating estrogen is mainly secreting from the ovary in premenopausal women, however, after menopause ,estrogen is biosynthesizing in peripheral tissues such as adipose tissues ,skin and muscles through conversion of circulating inactive steroids(Sasano \& Harada.,1998 ; Ma H et al ., 2006 ) as represented in estron produced by the peripheral conversion of androstendion, the precursor of testosterone(Miller.,1990).

Most breast tumor are of estrogen dependent and postmenopausal women with elevated serum estrogen are at an increased risk of developing breast cancer (The Endogenous Hormones and Breast Collaborative Group,2002).Malignant breast tumors produce large amounts of estrogen locally via overexpressing aromatase enzyme compared to their normal counterparts (Bulun et al.,2005).

The concentration of estradiol was 2.3 times higher in breast cancer tissues than in the areas as morphologically normal(Chetrite et al.,2000).

Biologically, it is known that endogenous estrogen bind specifically to estrogen receptor (ER) and influence tumor growth For instance, women whose tumors are positive for both ER respond better to endocrine therapy compared with those whose tumors are negative for both receptors. (Rayter ., 1991 ; Habel \& Stanford ., 1993).

For premenopausal patients with metastatic breast cancer, the classic treatment is ovariectomy (Beatson ., 1986).

the first clinical study with an LHRH analogue were reported by Klijn and de Jong 1982 Since then, a series of more than 13 phase II studies with various LHRH agonists, such as goserelin, buserelin, and others, have shown an objective response in $161(38 \%)$ of 419 patients (Klijn ., 1992).

Beside the LHRH analogue anti-estrogens are now widely used for the treatment of postmenopausal women with hormone dependent breast cancer antiestrogens, such as tamoxifen, tamoxifen is now the standard first-line therapy for postmenopausal metastatic breast cancer and is also accepted as an alternative to ovariectomy in premenopausal patients (Fossati et al ., 1998).

Tamoxifen block the interaction of estradiol (E2) with the estrogen receptor (ER) (Cole MP et al ., 1971; Smith IE \& Dowsett M ., 2003).

Tamoxifen is regarded as a pro-drug since two of its metabolites, 4hydroxytamoxifen (4OHtam) and 4-hydroxy-N-demethyltamoxifen (4OHNDtam, 


\section{University of Thi-Qar Journal Vol.10 No.2 June 2015}

Web Site: https://jutq.utq.edu.iq/index.php/main Email: journal@jutq.utq.edu.iq

endoxifen), both have estrogen receptor affinity markedly exceeding that of tamoxifen itself (Katzenellenbogen et al ., 1984 ; Johnson et al ., 2004) .

The 4OHNDtam is considered the main active metabolite of tamoxifen, since it has 100-fold higher affinity for the estrogen receptor (ER) than tamoxifen and is 10-fold higher in serum levels than 4OHtam (Borgna \& Rochefort., 1981; Gjerde et al ., 2008 ).

These potent metabolites are converted from tamoxifen through the cytochrome P450 (CYP) enzymes 2C19, 2D6, and 3A5. They are conjugated and deactivated through sulfotransferase (SULT) 1A1 (Desta et al ., 2004) in this research we investigated the effect of tamoxifen and LHRH analogue on estrogen level and the side effect of these drug on some liver enzymes when these drug metabolism in the liver.

\section{Material and methods :}

Are taking random samples of breast cancer patients under treatment of patients attending the Institute of Atomic Radiation in Baghdad, and specifically who use ( $20 \mathrm{mg} /$ day) of tamoxifen .100 samples of breast cancer and 30 sample as a control aged ( $20-80)$ years the collection of samples was conducted during the period from April 2013 to July 2013

Approximately $3 \mathrm{ml}$ of blood were collected from each women using standard procedures. The blood put in Spain tube allowed to stand at room temperature for at least one-half hour or until it was thoroughly clotted and then refrigerated within 2 hours of collection ,blood was centrifuged and serum was separated and put into sterile apendroff tubes ,the letters were labeled and stored at $70 \mathrm{C}^{\circ}$ (Dorgan et al.,2010).

\section{1- Measurement of Estaradiol hormone E2:}

Reagents according to Estaradiol E2 hormone kit, Monobind, USA.

\section{2- Measurement of the liver enzymes:}

Test for ( alkaline phosphate ALP, of gamma glutamyltransferase ( GGT ) or Y GT, glutathione oxidase transferase GOT, glutathione pyruvate transferase GPT in blood serum plasma with The Reflotron ${ }^{\circledR}$ System. 
University of Thi-Qar Journal Vol.10 No.2 June 2015

Web Site: https://jutq.utq.edu.iq/index.php/main Email: journal@jutq.utq.edu.iq

Measurement of lactate dehydrogenase ( LDH ) :Testes of LDH with linear chemical S.L, France ( kit)

\section{3- Statistical analysis :}

The statistical analysis of this study is made by using SPSS program (Version 10) and the statistical processes used here were Means, Standard deviations, One way ANOVA and Chi square .

\section{RESULTES:}

\section{1- Age}

The highest percentage of breast cancer patients under investigation was recorded in (41-60 years) with 58 cases (\%58) followed by 32 cases (\%32) were seen (20-40 y), and 10 cases (\%10) were seen in (61-80 y), table (1).

Table (1) Distribution patient breast cancer groups according to age .

\begin{tabular}{|c|c|c|c|c|}
\hline Studied groups & $0-40$ & $1-60$ & $1-80$ & $\begin{array}{ll}\chi^{2} \text { between } & \text { the } \\
\text { Categories } & \text { for } \\
\text { patient } & \end{array}$ \\
\hline $\begin{array}{l}\text { Patient group } \mathrm{n}= \\
100\end{array}$ & $111+1,1$ & 8 & 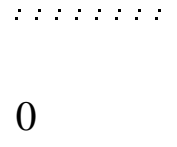 & 0.000 \\
\hline$\%$ & $32 \%$ & $58 \%$ & $10 \%$ & \\
\hline
\end{tabular}

\section{2- Estradiol hormone $\left(\mathbf{E}_{2}\right)$.}

The results of table (2) showed a significant decrease difference in the levels of estradiol hormone $E_{2}$ in group of breast cancer (37.3634 \pm 45.02893$)$ as compared with the control groups $(93.3700 \pm 51.07188)$.

Table (2) Serum estradiol hormone levels $\left(E_{2}\right)(\mathrm{pg} / \mathrm{ml})$ in control and patient groups .

\begin{tabular}{|c|c|c|}
\hline Studied groups & Mean \pm SD & Significant \\
\hline
\end{tabular}


University of Thi-Qar Journal Vol.10 No.2 June 2015

Web Site: https://jutq.utq.edu.iq/index.php/main Email: journal@jutq.utq.edu.iq

\begin{tabular}{|l|l|l|} 
Control group $\ldots \ldots \ldots \ldots$ & $93.3700 \pm 51.07188$ & \\
$\ldots \ldots \ldots \ldots \ldots \ldots$ & & \\
Patient group & $37.3634 \pm 45.02893$ & .000 \\
\hline
\end{tabular}

$\mathrm{P} \leq 0.01$

3- Liver function enzymes (Aspartate aminotransferase (AST), Alanine aminotransferase (ALT), Alkaline Phosphate ( ALP ), glutamyl transpeptidase (GGT), lactate dehydrogenase (LDH-5), Total Billirubin:

Results showed no significant differences in liver enzymes, as well as total bilirubin between patients group and the control group As in the table (3)

Table (3) the level of liver enzymes U / l, total bilirubin (mg / dl) between patients and the control group

\begin{tabular}{|c|c|c|c|}
\hline The liver enzymes & Studied Groups & Mean \pm Std . deviation & Significant \\
\hline \multirow[t]{2}{*}{ AST } & $\begin{array}{l}\text { Control group } \\
\text { Coul }\end{array}$ & $27.2100 \pm 3.61914$ & \multirow[t]{2}{*}{.296} \\
\hline & Patient group & $24.1865 \pm 15.63097$ & \\
\hline \multirow[t]{2}{*}{ ALT } & Control group & $31.7570 \pm 7.47237$ & \multirow[t]{2}{*}{.554} \\
\hline & Patient group & $34.7260 \pm 26.99979$ & \\
\hline \multirow[t]{2}{*}{ GGT } & 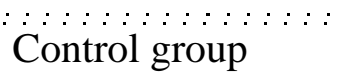 & $18.1733 \pm 3.98946$ & \multirow[t]{2}{*}{.084} \\
\hline & Patient group & $50.4226 \pm 101.14239$ & \\
\hline \multirow[t]{2}{*}{ ALP } & Control group & $83.42 \pm 22.58$ (intin & \multirow[t]{2}{*}{0.620} \\
\hline & Patient group & $89.64 \pm 67.21$ & \\
\hline \multirow[t]{2}{*}{$\mathrm{LDH}-5$} & Control group & $168.5333 \pm 39.23293$ & \multirow[t]{2}{*}{.654} \\
\hline & Patient group & $164.9100 \pm 38.58327$ & \\
\hline \multirow[t]{2}{*}{ Total billirubin } & Control group & $.08337^{6} .6473 \pm$ & \multirow[t]{2}{*}{.292} \\
\hline & Patient group & $.21078 \pm .6891$ & \\
\hline
\end{tabular}

\section{Discussion :}

\section{1- Age:}

In the present study maximum number of women with malignant breast cancer were observed in 41-60 years (58 cases) followed by 20-40 years (32 cases) 


\section{University of Thi-Qar Journal Vol.10 No.2 June 2015}

Web Site: https://jutq.utq.edu.iq/index.php/main Email: journal@jutq.utq.edu.iq

.The average age was 50 years .These results agreed with previous studies in Iraq(Waheda, 1998 ; Madhoor ,2002).

Age is the single most important risk factor in breast cancer. women are 10 times as likely to develop breast cancer in their thirties and twenties ,40 times as likely in their forties ,60 times as likely in their fifties and 90 times as likely after sixties(Forbes, 1997).

And agreed with other study that show in united state the higher percent $20 \%$ in age before 50 years and followed $4 \%$ in 40 and the higher infect in the third decades ( Howlader et al ., 2013).

\section{2- Estradiol hormone $\left(\mathbf{E}_{2}\right)$.}

The present study demonstrated that there was a significant lowering in the levels of serum estradiol hormone in women with breast cancer table (2) who were taking tamoxifen drug and LHRH analogue this result was supported by Jan et al ., 2000.

Estrogen can cause cancer by stimulating cell proliferation(promotion) and causing genotoxic damage(initiation), estrogen are highly mitogenic in hormone sensitive tissues such as breast, prolonged exposure of target tissues and cells to excessive mitogenic stimulation by estrogens has been considered an important etiological factor for induction breast cancer (Hiraku et al.,2001).Serum estradiol hormone levels were found to be associated with local estradiol levels in normal breast tissue of breast cancer patients, this strengthens the hypothesis that serum estradiol levels influence the gene expression in breast tissue(Lonning et al.,2009).

In the two groups of patients treated with buserelin ( LHRH analogue) alone or buserelin with tamoxifen, both the median and the mean levels of plasma estradiol dropped to normal postmenopausal values within 6 weeks and remained suppressed throughout treatment in all patients In the group treated with tamoxifen alone, however, plasma estradiol levels increased on average threefold to fourfold in nearly all patients.

The study also agreed with (Forward et al 2004 ) As it was found that giving tamoxifen treatment with giving hormone ((LHRH analogue ) lead to a lack of estrogen significantly. 


\section{University of Thi-Qar Journal Vol.10 No.2 June 2015}

Web Site: https://jutq.utq.edu.iq/index.php/main Email: journal@jutq.utq.edu.iq

And tamoxifen treatment is competitive with estrogen receptors in breast tissue (Marian et al ., 2011).

In another study confirmed that giving tamoxifen alone for women with breast cancer pre-menopause is working to increase the concentration of estrogen 2-3 times compared to women who did not taking of tamoxifen (Sherman ., 1979)

In three published randomized trials have compared combined hormonal therapy using tamoxifen and an LHRH analogue to endocrine monotherapy (the LHRH analogue in all but one of the trials) in premenopausal women with advanced breast cancer A meta-analysis of these trials has been performed, and it suggests that the combination is superiorto monotherapy for all end points, with significant benefits in mortality rate ( reduction in estradiol plasma level ), (22\% relative reduction), rate of disease progression (30\% relative reduction), rate of objective clinical response (39\% versus 30\%), and duration of response (19 months versus 11 months) (Boccardo et al ., 1994; Jonat et al ., 1995 ; Klijn et al ., 2000).

\section{3- Liver function enzymes (Aspartate aminotransferase (AST), Alanine} aminotransferase (ALT), Alkaline Phosphate ( ALP ), glutamyl transpeptidase (GGT), lactate dehydrogenase (LDH-5), Total Billirubin:

The liver is important organ that metabolized transformation and elimination different drugs (Miya et al ., 1991).

The metabolism of liver in two phases, the first phase include: oxidation , reduction, hydroxylation and mithelation by the enzyme system of Cytochrome P 450 located in the endoplasmic reticulum which is the most important enzyme in drug metabolism in the liver

While the second phase include: conjunction the chemical materials with aquoes compound like : glucoronide, sulfur compounds and amino acids and thus lead to the formation of intermediate compounds soluble in water and are easy to elimination (Kedderis ., 1996).

The last reaction occurs in the second stage is glutathione that works on conjunction intermediate compounds with glutathione-S transferase covalently that 
University of Thi-Qar Journal Vol.10 No.2 June 2015

Web Site: https://jutq.utq.edu.iq/index.php/main Email: journal@jutq.utq.edu.iq result in elimination of toxic intermediate compounds that may cause hepatotoxicity ( Lee ., 1995)

For this reason the test of liver enzymes are necessary for liver health (El-Beshbishya et al ., 2010)

In recent study the liver enzymes and billirubin are measured and show there are no significant different and agreed with ( Degregorio et al ., 1989) the results of this study show that the high doses of tamoxifen $20 \mathrm{mg}$ twice in a day causes damage in the liver by rising ALT, ALP , AST and total billirubin while GGT and LDH didn't show any change in high doses but when the doses of tamoxifen was reduced all enzymes and billirubin become normal .

Another study appeared that the tamoxifen with normal dose $10 \mathrm{mg}$ twice in day didn't affected in liver enzymes and billirubin (Floren et al ., 1998) .

While ( El-Beshbishya et al ., 2010) appeared the high doses of tamoxifen consider toxic and cause hepatotoxicity and raises sGOT, sGPT, sLDH, sALP and s GGT in rates but this not approved on the human .

And the studies (Sharma R et al ., 2003 ; Jakesz R et al ., 2002 Jan G. M. Klijn et al ., 2000 ) showed that the treatment with tamoxifen and LHRH analogue didn't affected on the liver.

\section{References}

Allred DC, Brown P, Medina D. ( 2004 ) The origins of estrogen receptor appositive and estrogen receptor a-negative human breast cancer. Breast Cancer Res;6:240-5.

Bernstein L, Ross RK (1993) : Endogenous hormones and breast cancer risk. Epidemiol Rev 15:48-65.

Beatson AT (1986): . On the treatment of inoperable cases of carcinoma mamma:suggestions for a new method of treatment with illustrative cases. Lancet ;2:104-17.

Boccardo F, Rubagotti A, Perrotta A et al (1994): Ovarian ablation 


\section{University of Thi-Qar Journal Vol.10 No.2 June 2015}

Web Site: https://jutq.utq.edu.iq/index.php/main Email: journal@jutq.utq.edu.iq

Borgna JL, Rochefort H. (1981) : Hydroxylated metabolites of tamoxifen are formed in vivo and bound to estrogen receptor in target tissues. J Biol Chem, 256(2):859-868.

Bulun,S.E.; Lin,Z.; Imir,G.; Amin,S.; Demura,M.; Yilmaz,B. et al.(2005). Regulation of aromatase expression in estrogen-responsive breast and uterine disease: from bench to treatment. Pharmacol Rev.;57:359-383

buserelin and tamoxifen in premenopausal metastatic breast cancer:a randomized study. J Natl Cancer Inst;92:903-911.

\section{Chetrite,G.S.; Cortes-Prieto,J.; Philippe,J.C.; Wright,F. and Pasqualini,J.R.} (2000). Comparison of estrogen concentrations, estrone sulfatase and aromatase activities in normal, and in cancerous, human breast tissues. $J$. of Ster. Biochem. and Mol. Bio.72 23-27.

Cole MP, Jones CTA and Todd IDH . (1971) : A new anti-estrogenic agent in late breast cancer. An early appraisal of ICI 46,474. Br JCancer 25: 270-275,

Degregorio MW, WiebeVJ, Venook AP et al (1989): . Elevated plasma tamoxifen levels in a patient with liver obstruction. Cancer ChemotherPharmacol; 23: 194-5.

Desta Z, Ward BA, Soukhova NV, Flockhart DA. (2004): Comprehensiv evaluation of tamoxifen sequential biotransformation by the humancytochrome P450 system in vitro: prominent roles for CYP3A andCYP2D6. J Pharmacol Exp Ther, 310(3):1062-1075.

Dorgan,F.J.;Stanczyk,Z.F.;Kahle,L.L.;andBrinton,A.L.(2010). Prospective casecontrol study of premenopausal serum estradiol and testosterone levels and breast cancer risk. J.Breast cancer research .12:98.

Forbes, J.F.(1997). The incidence of breast cancer: the global burden, public health considerations. Seminars in Oncology 24(1, suppl 1):S1-20-S1-35

Forward DP, Cheung KL, Jackson L, et al(2004) . Clinical and endocrine data for goserelin plus anastrozole as second-line endocrine therapy for premenopausal advanced breast cancer. Br J Cancer 90:590-594.

Fossati R, Confalonieri C, Torri V, Ghislandi E, Penna A, Pistotti V, et. Al (1998): Cytotoxic and hormonal treatment for metastatic breast cancer: a 
University of Thi-Qar Journal Vol.10 No.2 June 2015

Web Site: https://jutq.utq.edu.iq/index.php/main Email: journal@jutq.utq.edu.iq

systematic review of published randomized trials involving 31,510 women. J Clin Oncol;16:3439-60.

Gjerde J, Hauglid M, Breilid H, Lundgren S, Varhaug JE, Kisanga ER,Mellgren G, Steen VM, Lien EA. (2008): Effects of CYP2D6 and SULT1A1genotypes including SULT1A1 gene copy number on tamoxifenmetabolism. Ann Oncol, 19(1):56-61.

Goldfien,A. and Monroe,S.E.(1997) Ovaries. In: Basic and Clinical Endocrinology. (5th Edition). Eds. F.S. Greenspan and G.J. Strewler. Appleton \& Lange, Stamford, p434, 1997.

Habel LA, Stanford JL (1993) : Hormone receptors and breast cancer. Epidemiol Rev 15:209-219.

Hall,J.M.; Couse,J.F. et al. (2001). The multifaceted mechanisms of estradiol and estrogen receptor signaling. J. Biol. Chem. 276(40): 36869-72.

Hesham A El-Beshbishya, Ahmed M Mohammad, Ayman A Nagyc and Ashraf ( 2010 ): Amelioration of tamoxifen-induced liver injury in rats by grape seed extract, black seed extract and curcumin. Indian Journal of Experimental Biology Vol. 48, : pp. 280-288

Hiraku,Y.; Yamashita,N.; Nishiguchi,M. and Kawanishi,S.(2001). Catechol estrogens induce oxidative DNA damage and estradiol enhances cell proliferation. International J. of Cancer vol.92(3):333-337.

Howlader N, Noone AM, Krapcho M, et al (2013). eds. SEER Cancer Statistics Review, 1975- 2010. Bethesda, MD: National Cancer Institute.

Hulka BS. (1996): Epidemiology of susceptibility to breast cancer. Prog Clin Biol Res 395:159-174.

Iraqi Cancer Registry (2008). Iraqi Cancer Board, Ministry of Health Baghdad Iraq, 2010

Jan G. M. Klijn, Louk V. A. M. Beex, Louis Mauriac, Jacobus A. van Zijl, Corinne Veyret, Johan Wildiers, Jacek Jassem, Martine Piccart, Jos Burghouts, Dominique Becquart, Carolien Seynaeve, Franc oise Mignolet, Luc Duchateau (2000): Combined Treatment With Buserelin and Tamoxifen in Premenopausal Metastatic Breast Cancer: a 
University of Thi-Qar Journal Vol.10 No.2 June 2015

Web Site: https://jutq.utq.edu.iq/index.php/main Email: journal@jutq.utq.edu.iq

Randomized Study. Journal of the National Cancer Institute; Vol. 92, No. 11.

Johnson MD, Zuo H, Lee KH, Trebley JP, Rae JM, Weatherman RV, Desta Z,Flockhart DA, Skaar TC . (2004) : Pharmacological characterization of 4-hydroxy-N-desmethyl tamoxifen, a novel active metabolite of tamoxifen. Breast cancer research and treatment, 85(2):151-159.

Jonat W, Kaufmann M, Blamey RW et al (1995): A randomized study to compare the effect of the luteinising hormone releasing hormone (LHRH) analogue goserelin with or without tamoxifen in pre- and perimenopausal patients with advanced breast cancer. Eur J Cancer;31A:137-142.

Katzenellenbogen BS, Norman MJ, Eckert RL, Peltz SW, Mangel WF. (1984) :Bioactivities, estrogen receptor interactions, and plasminogenactivatorinducing activities of tamoxifen and hydroxy-tamoxifenisomers in MCF-7 human breast cancer cells. Cancer Res,44(1):112-119.

Kedderis GL (1996): Biochemical basis of hepatocellular injury. Toxicol Pathol 24: 77-83.

Klijn JG . (1992): LHRH analogs in the treatment of metastatic breast cancer: ten years' experience. In: Hoffken K, editor. Peptides in oncology: LHRH agonists and antagonists. Berlin (Germany): Springer-Verlag; p.75-90.

Klijn JG, Beex LV, Mauriac $L$ et al (2000): Combined treatment with versus goserelin with or without tamoxifen in pre-perimenopausal patients with advanced breast cancer: results of a multicentric Italian study. Ann Oncol;5:337-342.

Klijn JG, de Jong FH (1982): . Treatment with a luteinising-hormone-releasing hormone analogue (buserelin) in premenopausal patients with metastatic breast cancer. Lancet;1:1213-6.

L. C. Floren, M. F. Hebert, A. P.Venook V. C Jordan, A. Cisneros \& K. A. Somberg ( 1998): Tamoxifen in liver disease: Potential exacerbation of hepatic dysfunction. Annals of Oncology 9: 1123-1126,1998.

Lee WM (1995) : Medical progress: Drug-induced hepatotoxicity. N Engl J Med 333: 1118-1127.

Lonning,P.E.; Helle,H.; Duong,N.K.; Ekse,D.; Aas,T.;and Geisler,J.(2009). Tissue estradiol is selectively elevated in receptor positive breast cancers 
University of Thi-Qar Journal Vol.10 No.2 June 2015

Web Site: https://jutq.utq.edu.iq/index.php/main Email: journal@jutq.utq.edu.iq

while tumour estrone is reduced independent of receptor status. J. Steroid Biochem. Mol.Biol. 117:31-41.

Ma H, Bernstein L, Pike MC, Ursin G ( 2006 ) . Reproductive factors and breast cancer risk according to joint estrogen and progesterone receptor status: a meta- nalysis of epidemiological studies. Breast Cancer Res;8:R43.

Mark E. Sherman, David L. Rimm, Xiaohong R. Yang, Nilanjan Chatterjee, Louise A. Brinton1, Jolanta Lissowska, Beata Peplonska, Neonila Szeszenia-Da cbrowska, Witold Zatonski, Richard Cartun, Daniza Mandich, Grzegorz Rymkiewicz, Marcin Ligaj, Stanisław Lukaszek, Radzislaw Kordek, Zynep Kalaylioglu, Malini Harigopa,Lori Charrette, Roni T. Falk, Douglas Richesson, William F. Anderson, Stephen M. Hewitt and Montserrat Garc_la-Closas ( 2007) . Variation in breast cancer hormone receptor and HER2 levels by etiologic factors: A population-based analysis . Int. J. Cancer: 121, 1079-1085.

Madhoor,B.M.(2002).Immunological Study on Patients with Breast Cancer. Msc. thesis College of medicine .University Al-Mustansiriyah.

Manly,J.J.; Merchant,C.A. et al. (2000). "Endogenous estrogen levels and Alzheimer's disease among postmenopausal women." Neurology 54(4): 833-7.

Marian Y. Williams-Browna, Sana M. Salihb, Xia Xuc, Timothy D. Veenstrac, Muhammad Saeedd, Shaleen K. Theilera,e, Concepcion R. DiazArrastiaa,e, and Salama A. Salamaa (2011 ). The effect of tamoxifen and raloxifene on estrogen metabolism and endometrial cancer risk : Steroid Biochem Mol Biol. 126(3-5): 78-86.

Miller,W.R.(1990) .Oestrogens and breast cancer: Biological considerations. $B r$. Med. Bull. 47: 470

Miyai K, Meeks RG, Harrison SD, Bull RJ (1991) : Structural organization of the liver. In: Hepatotoxicology. CRC Press, Boca Raton, FL.

Rayter Z (1991) : Steroid receptors in breast cancer. Br J Surg 78:528-535.

Russo,I.H. and Russo,J.(2005). The role of estrogen in breast cancer. In: Russo J, Russo IH, editors. Molecular Basis of Breast Cancer Prevention and Treatment. Springer-Verlag; Heidelberg: pp. 89-136. 
University of Thi-Qar Journal Vol.10 No.2 June 2015

Web Site: https://jutq.utq.edu.iq/index.php/main Email: journal@jutq.utq.edu.iq

Sasano,H. and Harada,N. (1998) .Intratumoral aromatase in human breast, endometrial, and ovarian malignancies. Endocrine Reviews 19 593-607.

Sherman BM, Chapler FK, Crickard K, Wycoff D (1979) . Endocrine consequences of continuous antiestrogen therapy with tamoxifen in premenopausal women. J Clin Invest;64:398-404.

Smith IE and Dowsett M. (2003) : Aromatase inhibitors in breast cancer.N Engl J Med 348: 2431-2442, 2003.

Stanczyk,F.Z.(1997) Steroid hormones. In: Mishell's Textbook of Infertility, Contraception, and Reproductive Endocrinology. 4th edition.Edited by Lobo RA, Mishell DR, Paulson RJ, Shoupe D. Oxford:Blackwell Science; :47-66.

The Endogenous Hormones Breast Cancer Collaborative Group.(2002). Endogenous sex hormones and breast cancer in postmenopausal women: reanalysis of nine prospective studies. J. Natl. Cancer Inst.94:606 - 16.

Tivis,L.J.; Richardson,M.D. et al. (2005). "Saliva versus serum estradiol: implications for research studies using postmenopausal women." Prog. Neuropsychopharmacol Biol. Psychiatry 29(5): 727-32.

Waheda, N. Elia.(1998).A study of certain immunological parameters in women a fflicted with breast cancer in Iraq. Ph D, College of Science. University of Baghdad 